\title{
MANUFACTURING OF High QUALITY MiNiATURE GEARS BY WiRE ElECTRIC DisCHARGE MACHINING
}

\author{
GUPTA, K. \& JAIN, N.K.
}

Abstract: This chapter presents the manufacturing of high quality miniature spur gears of brass by Wire Electric Discharge Machining (WEDM). Effects of four WEDM parameters i.e. voltage, pulse-on time, pulse-off time and wire feed rate on five responses namely profile error, pitch error, average roughness, maximum roughness and material removal rate are studied. The experimental research was accomplished in three stages namely pilot, main and confirmation experimentation. The bracketed range of WEDM parameters by pilot experimentation were used in the main experiments designed using Box-Behnken approach of response surface methodology (RSM) and finally the confirmation experiments were conducted to validate the optimum results predicted by desirability anaylsis. The miniature gears manufactured by WEDM had defect-free microstructure, very thin recast layer, good surface finish and having gear quality upto DIN standard 5 for micro-geometry parameters (i.e. profile and pitch) which is much superior than the quality of the miniature gears manufactured by other existing conventional processes.

Key words: WEDM, miniature gears, profile, pitch, RSM
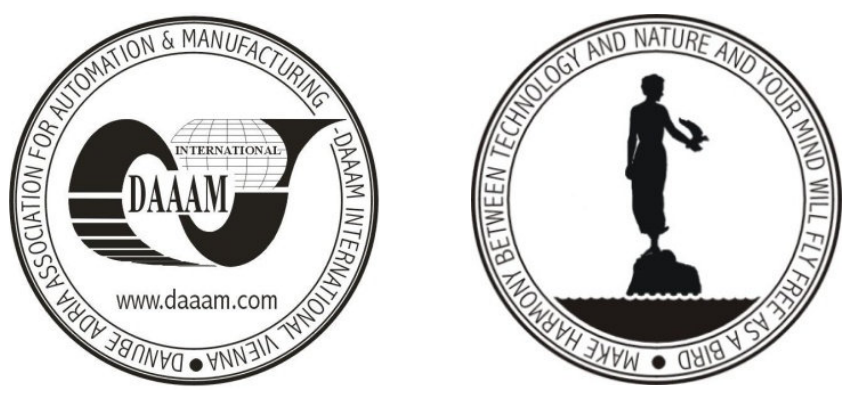

Authors' data: Gupta, K[apil]; Jain, N[eelesh] K[umar], Discipline of Mechanical Engineering, Indian Institute of Technology Indore, 453446, MP, India, kapil@iiti.ac.in,nkjain@iiti.ac.in

This Publication has to be referred as: Gupta, K[apil] \& Jain, N[eelesh] K[umar] (2013) Manufacturing of High Quality Miniature Gears by Wire Electric Discharge Machining, Chapter 40 in DAAAM International Scientific Book 2013, pp. 679-696, B. Katalinic \& Z. Tekic (Eds.), Published by DAAAM International, ISBN 978-3901509-94-0, ISSN 1726-9687, Vienna, Austria

DOI: $10.2507 /$ daaam.scibook.2013.40 
Gupta, K. \& Jain, N.K.: Manufacturing of High Quality Miniature Gears by Wire E...

\section{Introduction}

In recent years the demand for high-accuracy fine pitch miniature gears has increased and is expected to continue its upward trend in the future also as the emphasis towards the miniaturization continues. The gears having outside diameter less than $10 \mathrm{~mm}$ are categorized as miniature gears. Miniature gears can be further subdivided as micro-gears (outside diameter $<1 \mathrm{~mm}$ ) and meso-gears (outside diameter in the range of 1-10 mm). Miniature gears are one of the key components of the highly accurate miniaturized devices such as miniature motors and pumps, electronic and home appliances, business machines, automotive parts, timing devices, measuring instruments, MEMS and NEMS, etc. used in the scientific, industrial and domestics areas. Functional characteristics of these miniaturized devices depend on the quality of the miniature gears used. Therefore, highly accurate and advanced manufacturing processes are required for fabrication of high quality miniature gears. The present work is concerned with investigations on manufacturing of high quality meso-gears by WEDM. Brass, bronze, aluminium, stainless steel are the most commonly used materials for these gears (Davis, 2005; Townsend, 2011). Gears made of brass are primarily used as motion transmitting gears which are fine pitched and generally run at very high speed. Therefore, accurate motion transfer, minimum running noise and longer service life are the important desirable characteristics for these gears.

The conventional processes for manufacturing the miniature gears include hobbing, stamping, extrusion, die casting and powder metallurgy. But, these processes suffer from some inherent limitations as mentioned in the Table 1. Moreover, all these processes manufacture gears of low quality i.e. Deutsche normen (DIN) quality number is in the range of 9-12 (Bralla, 1998; Davis, 2005; Townsend, 2011). DIN and American gear manufacturers association (AGMA) are the international standards defining the quality of the gears in terms of micro-geometry parameters. Lower DIN number or higher AGMA number indicates better quality of the gear and vice-versa. Table 2 presents the quality requirements of the gears for various applications in terms of DIN and AGMA numbers along with the manufacturing processes used for the miniature gears.

\subsection{Micro-Geometry of Miniature Gears}

The important micro-geometry parameters of gears affecting their operating performance and service life include errors or deviations in the profile, lead, pitch, runout and surface roughness. Fig. 1 depicts the effects of these micro-geometry parameters on the performance characteristics of the gears. The profile error affects the noise behaviour, lead error governs the load carrying capacity while, pitch error and runout affect the motion transfer characteristics (Fig. 1) (Goch, 2003; Townsend, 2011). Profile error and lead error are the form errors while, pitch error and runout are the position or location errors. Form errors are the deviations from the intended nominal shape of the gear tooth surface, whereas location errors are related to the accuracy of location of teeth on a gear. Profile errors or deviations include form and 
angle (slope) deviation of the gear tooth profile from the nominal (intended) involute tooth profile, and are measured perpendicular to the functional profile.

\begin{tabular}{|c|c|c|}
\hline $\begin{array}{l}\text { Miniature gear } \\
\text { manufacturing } \\
\text { process }\end{array}$ & Limitations & $\begin{array}{l}\text { DIN quality } \\
\text { number }\end{array}$ \\
\hline Hobbing & $\begin{array}{l}\text { - Replicates tool marks on gear teeth } \\
\text { - Needs subsequent polishing operation for high quality gears } \\
\text { - Requires long set-up time. }\end{array}$ & 9 \\
\hline Stamping & $\begin{array}{l}\text { - Necessitates shaving operation for final finishing of gears } \\
\text { - Cannot manufacture gears with higher tooth thickness } \\
\text { - Wear \& Tear of die and punch is a problem in stamping. }\end{array}$ & 10 \\
\hline Die-Casting & $\begin{array}{l}\text { - Cannot be used where extreme accuracy is needed } \\
\text { - Subsequent trimming operations are necessary after the gear has } \\
\text { been removed from the die. }\end{array}$ & 11 \\
\hline Extrusion & $\begin{array}{l}\text { - Requires secondary drawing operation for improving accuracy of } \\
\text { gears } \\
\text { - Wear of die is a major problem. }\end{array}$ & 12 \\
\hline $\begin{array}{l}\text { Powder } \\
\text { Metallurgy }\end{array}$ & $\begin{array}{l}\text { - } \text { De-binding of part from mould is difficult } \\
\text { - } \\
\text { - }\end{array}$ & 10 \\
\hline
\end{tabular}

Tab. 1. Limitations of conventional processes for manufacturing of miniature gears with corresponding DIN quality

\begin{tabular}{|c|c|c|c|c|}
\hline $\begin{array}{l}\text { Application } \\
\text { type }\end{array}$ & $\begin{array}{l}\text { Typical } \\
\text { examples }\end{array}$ & $\begin{array}{l}\text { AGMA } \\
\text { quality } \\
\text { number }\end{array}$ & $\begin{array}{l}\text { DIN } \\
\text { quality } \\
\text { number }\end{array}$ & $\begin{array}{l}\text { Corresponding manufacturing } \\
\text { or finishing process }\end{array}$ \\
\hline \multirow[t]{5}{*}{$\begin{array}{l}\text { Commercial } \\
\text { applications }\end{array}$} & \multirow{5}{*}{$\begin{array}{l}\text { Hand tools, } \\
\text { Pumps, Clocks, } \\
\text { Slow speed } \\
\text { machineries, } \\
\text { Various } \\
\text { appliances }\end{array}$} & 3 & & $\begin{array}{l}\text { Plaster-mold casting, Permanent-mold } \\
\text { casting }\end{array}$ \\
\hline & & 4 & 12 & $\begin{array}{l}\text { Investment casting, Injection molding, } \\
\text { Extrusion }\end{array}$ \\
\hline & & 5 & 11 & Die casting ${ }^{*}$ \\
\hline & & 6 & 10 & $\begin{array}{l}\text { Milling, Cold drawing, Stamping }{ }^{*} \text {, Powder } \\
\text { metallurgy }\end{array}$ \\
\hline & & 7 & & Rolling, Broaching \\
\hline \multirow{5}{*}{$\begin{array}{l}\text { Precision } \\
\text { applications }\end{array}$} & \multirow{5}{*}{$\begin{array}{l}\text { Aircraft engines, } \\
\text { Turbines, } \\
\text { Cameras, } \\
\text { Automatic } \\
\text { transmission } \\
\text { systems, } \\
\text { Instruments, } \\
\text { High speed } \\
\text { machineries }\end{array}$} & 8 & $9-10$ & Rolling, Shaping, Hobbing ${ }^{*}$ \\
\hline & & 9 & $8-9$ & $\begin{array}{l}\text { Rolling, Shaving, Honing, Lapping, } \\
\text { Grinding }\end{array}$ \\
\hline & & 10 & $7-8$ & Shaving, Honing, Lapping, Grinding \\
\hline & & 11 & $6-7$ & Shaving, Grinding \\
\hline & & $12-13$ & $4-6$ & Grinding \\
\hline \multirow{2}{*}{$\begin{array}{l}\text { Ultra- } \\
\text { precision } \\
\text { applications }\end{array}$} & \multirow{2}{*}{$\begin{array}{l}\text { Precision } \\
\text { instruments, } \\
\text { Military } \\
\text { navigations }\end{array}$} & 14 & $3-4$ & Grinding \\
\hline & & 15 & $1-2$ & Grinding with extra care \\
\hline
\end{tabular}

* used for manufacturing of the miniature gears

Tab. 2. Quality requirements of the gears for various applications in terms of DIN and AGMA standards (Bralla, 1998; Davis, 2005; Townsend, 2011) 
Gupta, K. \& Jain, N.K.: Manufacturing of High Quality Miniature Gears by Wire E...

Lead errors or deviations include lead form deviation and lead angle (slope) deviation of the gear tooth flank along the face width and are measured at the middle of the tooth height. Pitch error is the difference between the nominal angular locations of the gear flanks to the actual measured locations. Runout is the maximum difference of the nominal radial position of all the teeth to the actual measured position. Both pitch errors and runout are measured at the middle of the tooth height. The geometric inaccuracy of a gear is caused due to the above said errors.

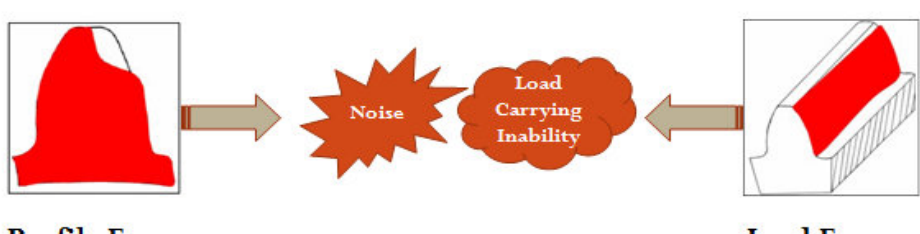

Profile Error

Lead Error

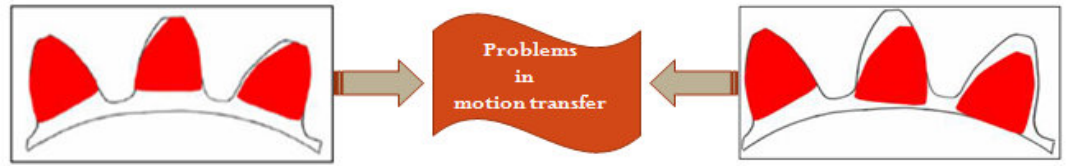

Pitch Error

Runout

Fig. 1. Effects of micro-geometry errors on performance of miniature gears

Surface roughness refers to short-wavelength and high frequency closely spaced irregularities on the surface which are caused by the nature and the actions of the manufacturing processes (Davim, 2010). Surface roughness affects the fatigue life of the components and this particularly important for the components subjected to dynamic loading such as gears. Two most important surface roughness parameters are average surface roughness ' $R_{a}$ ' and maximum surface roughness ' $R_{t}$ '. Higher surface roughness (i.e. presence of nicks, burrs, peaks and asperities) leads to early failure by occurrence of wear. Therefore, surface roughness should be minimized to prevent early failure of the gears.

\subsection{Introduction to WEDM}

High quality finish, better dimensional accuracy, burr-free surfaces and excellent repeatability are some of the important characteristics of WEDM (Benedict, 1987; Ho et al., 2004; Jain, 2008; McGeough, 1988). Therefore, WEDM has been recognized as a potential substitute to the conventional processes for micromachining and miniaturization applications (Gupta and Jain, 2013a-b; Hsu, 2008; Qin, 2010). In WEDM, the material is removed by the thermoelectric erosion process involving melting and vaporization caused due to the electric spark occurring between the wire and the workpiece material. For spark generation, the series of electrical pulses generated by the pulse generator is applied across the inter-electrode gap (IEG) between wire and workpiece in the presence of a dielectric. In the event of spark discharge, there is a flow of current across the IEG. Energy contained in a tiny spark discharge removes a fraction of workpiece material. Large number of such time 
spaced tiny discharges between the workpiece and wire electrode cause the electroerosion of the workpiece material. Fig. 2 illustrates the working principle of WEDM.

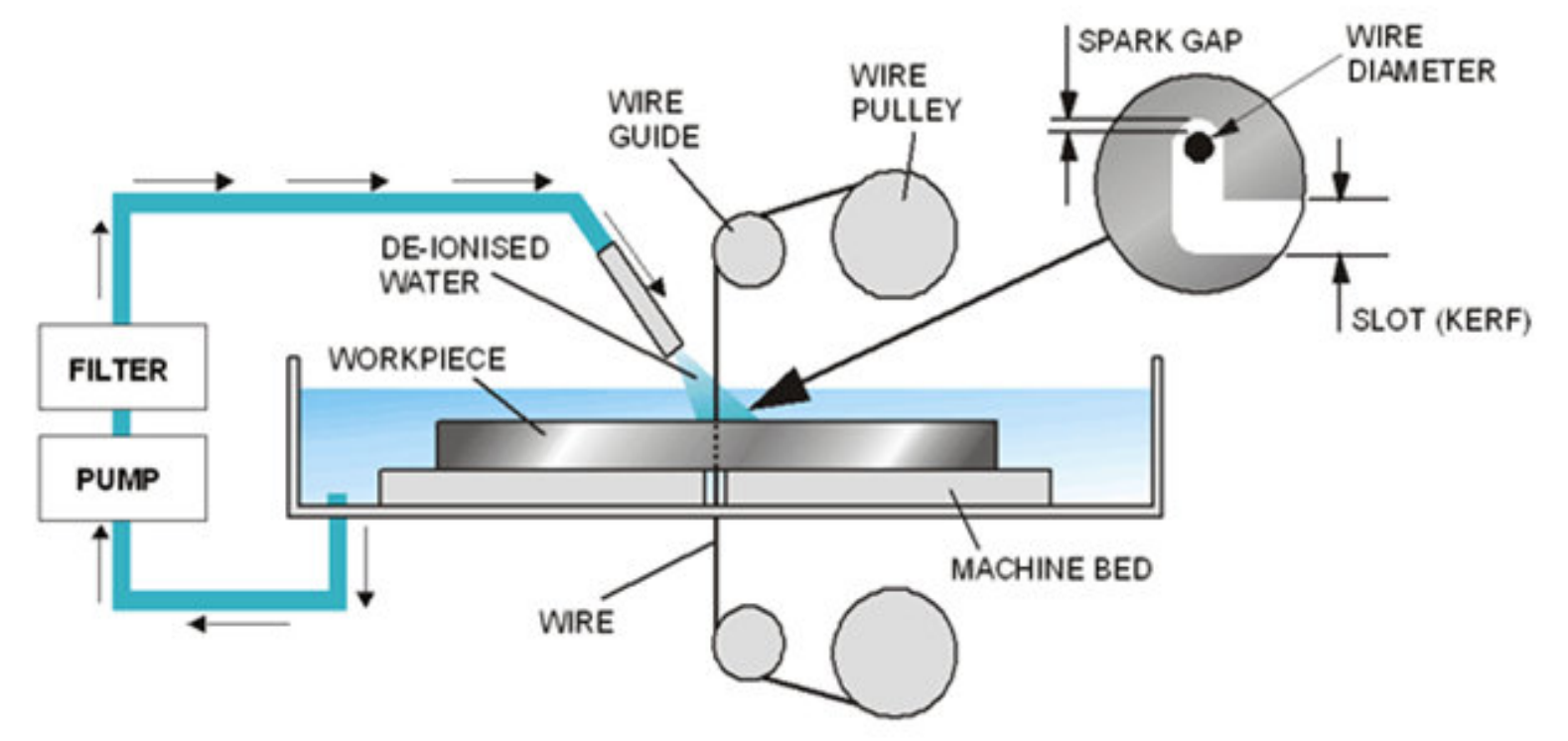

Fig. 2. Working principle of WEDM

The main causes of micro-geometry errors in WEDMed products are irregular shaped craters produced by violent spark at high discharge energy parameter settings, short circuiting, adherence of wire to the workpiece surface, and deflection of wire from its path known as wire lag (Arunachalam et al., 2001; Ho et al., 2004; Liao et al., 2004; Mingqi et al., 2005; Puri et al., 2003). The wire lag is caused due to impact of the mechanical forces produced by pressure from the gas bubbles, the axial forces applied to straighten the wire, the hydraulic forces induced by the dielectric flushing, the electro-static forces acting on the wire, and the electro-dynamic forces inherent to the spark generation.

\section{Literature Survey}

There are very few references available on manufacturing of miniature gears by WEDM or EDM-based processes. Takeuchi et al. (2000) developed a microplanetary gear system of SKS3 tool steel and WC-Ni-Cr cermets of $0.03 \mathrm{~mm}$ module with the help of micro-EDM. The manufactured gears were found good in torque transmission performance. Benavides et al. (2002) manufactured miniature ratchet wheel of different materials (e.g. 304L stainless steel, nitronic 60, austenitic stainless, beryllium copper, and titanium) by micro-WEDM with submicron level surface finish, minimum recast layer and consistent micro-geometry. Di et al. (2006) machined miniature gears of $40 \mu \mathrm{m}$ module and having seven teeth, from stainless steel plate of $1 \mathrm{~mm}$ thickness with an accuracy of $\pm 0.2 \mu \mathrm{m}$. Ali and Mohammad (2008) reported $1.4 \mu \mathrm{m}$ as $R_{a}$ and $7 \mu \mathrm{m}$ as $R_{t}$ for the miniature copper gear machined 
at $1 \mathrm{~A}$ discharge current, $8 \mathrm{~V}$ voltage and $8 \mu$ s pulse-on time by WEDM. Thereafter, Ali et al. (2010) obtained average surface roughness $\left(R_{a}\right)$, peak-to-valley height $\left(R_{t}\right)$ and dimensional accuracy of $1.8 \mu \mathrm{m}, 7 \mu \mathrm{m}$ and 2-3 $\mu \mathrm{m}$ respectively for WEDMed external spur gear of beryllium-copper having $3.58 \mathrm{~mm}$ diameter with seventeen teeth and $6 \mathrm{~mm}$ face width. Many attempts have been made in the recent past on improving the quality of WEDMed components by using various optimization methodologies (Kanlayasiri et al., 2013; Kuruvila et al., 2011; Tzeng et al., 2011; Yusup et al., 2012).

The review of past work reveals that no work has been reported on studying the behaviour of micro-geometry parameters (i.e. profile and pitch) of miniature gears with WEDM parameters. It can also be concluded that no literature seems to be available on optimization of parameters of WEDM for improving the manufacturing quality in terms of minimization of micro-geometry errors (errors in profile and pitch, and surface roughness of miniature gears). Also, productivity concept has not been taken care of in the previous work on WEDM of miniature gears. The present work bridges this gap by analyzing the behaviour of pitch, profile, surface roughness and material removal rate with the WEDM parameters and optimizing them for manufacturing high quality miniature gears.

\section{Objectives of the Research Work}

The prime objectives of the present research work were:

1. To explore the capability of WEDM for manufacturing high quality miniature gears.

2. To analyze the effect of WEDM parameters on micro-geometry, surface finish and material removal rate of the miniature gears.

3. To optimize the WEDM parameters to minimize the profile error, pitch error, average roughness, maximum roughness and maximize the MRR.

4. To establish WEDM as a superior alternative process for manufacturing the high quality miniature gears.

\section{Research Methodology}

The experimental research was accomplished in three stages namely pilot, main and confirmation experimentations. Table 3 presents the objectives, the input parameters, responses, design of experiments (DOE) approach and number of experiments conducted during each stage along with the specification of miniature gears manufactured. Pilot experiments were aimed to bracket the range of WEDM parameters and to fix the level of cutting speed for further research. Total twenty three experiments were designed based on one factor-at-a-time approach varying voltage, pulse-on time, pulse-off time and wire feed rate at five levels and cutting speed at three levels. The results of the pilot experiments gave a brief idea about the micro-geometry and surface integrity of WEDMed miniature gears. 


\begin{tabular}{|c|c|c|c|c|}
\hline $\begin{array}{c}\text { Experimentation } \\
\text { stage }\end{array}$ & Objectives & $\begin{array}{l}\text { Input parameters } \\
\text { with levels }\end{array}$ & Responses & $\begin{array}{c}\text { DOE } \\
\text { approach } \\
\text { (No. of } \\
\text { experiments) }\end{array}$ \\
\hline \multirow[t]{6}{*}{$\begin{array}{l}\text { Pilot } \\
\text { Experiments }\end{array}$} & \multirow{6}{*}{$\begin{array}{l}\text { To analyse the } \\
\text { behaviour of micro- } \\
\text { geometry parameters } \\
\text { with WEDM } \\
\text { parameters. } \\
\text { To bracket the range of } \\
\text { WEDM parameters for } \\
\text { further investigations. } \\
\text { To fix the cutting speed } \\
\text { for further } \\
\text { experimentation. } \\
\text { To analyse the surface } \\
\text { integrity of miniature } \\
\text { gears. }\end{array}$} & $\begin{array}{l}\text { 1. Voltage (V): } \\
5-10-15-20-25\end{array}$ & Profile error $(\mu \mathrm{m})$ & \multirow{6}{*}{$\begin{array}{l}\text { One factor } \\
\text { at-a- time } \\
(23)\end{array}$} \\
\hline & & $\begin{array}{l}\text { 2.Pulse-on time }(\mu \mathrm{s}) \text { : } \\
0.6-0.8-1-1.2-1.4\end{array}$ & Pitch error $(\mu \mathrm{m})$ & \\
\hline & & $\begin{array}{l}\text { 3.Pulse-off time }(\mu \mathrm{s}) \\
90-130-170-210-250\end{array}$ & Avg. roughness $(\mu \mathrm{m})$ & \\
\hline & & $\begin{array}{l}\text { 4. Wire feed rate: } \\
3-6-9-12-15(\mathrm{~m} / \mathrm{min})\end{array}$ & Max. roughness $(\mu \mathrm{m})$ & \\
\hline & & \multirow{2}{*}{$\begin{array}{l}\text { 5. Cutting speed } \\
(\%) *: 50-75-100\end{array}$} & Microstructure & \\
\hline & & & Micro-hardness & \\
\hline \multirow[t]{5}{*}{$\begin{array}{l}\text { Main } \\
\text { Experiments }\end{array}$} & \multirow{5}{*}{$\begin{array}{l}\text { To analyse the effect of } \\
\text { WEDM parameters and } \\
\text { interactions between } \\
\text { them on the responses. } \\
\text { To further facilitate the } \\
\text { optimization }\end{array}$} & $\begin{array}{l}\text { 1. Voltage }(\mathrm{V}) \text { : } \\
5-10-15\end{array}$ & Profile error $(\mu \mathrm{m})$ & \multirow{5}{*}{$\begin{array}{l}\text { Box- } \\
\text { Behnken of } \\
\operatorname{RSM}(29)\end{array}$} \\
\hline & & $\begin{array}{l}\text { 2. Pulse-on time } \\
(\mu \mathrm{s}): 0.6-0.8-1\end{array}$ & Pitch rrror $(\mu \mathrm{m})$ & \\
\hline & & $\begin{array}{l}\text { 3. Pulse-off time } \\
(\mu \mathrm{s}): 90-130-170\end{array}$ & Avg. roughness $(\mu \mathrm{m})$ & \\
\hline & & \multirow{2}{*}{$\begin{array}{l}\text { 4. Wire feed rate: } \\
9-12-15(\mathrm{~m} / \mathrm{min})\end{array}$} & Max. roughness $(\mu \mathrm{m})$ & \\
\hline & & & $\operatorname{MRR}\left(\mathrm{mm}^{3} / \mathrm{min}\right)$ & \\
\hline \multirow{5}{*}{$\begin{array}{l}\text { Confirmation } \\
\text { Experiments }\end{array}$} & \multirow{5}{*}{$\begin{array}{l}\text { To validate the optimum } \\
\text { results predicted by } \\
\text { desirability analysis. }\end{array}$} & \multirow{5}{*}{$\begin{array}{l}\text { Optimized } \\
\text { WEDM parameters }\end{array}$} & Profile Error $(\mu \mathrm{m})$ & \multirow[t]{5}{*}{$(5)$} \\
\hline & & & Pitch Error $(\mu \mathrm{m})$ & \\
\hline & & & Avg. roughness $(\mu \mathrm{m})$ & \\
\hline & & & Max. roughness $(\mu \mathrm{m})$ & \\
\hline & & & $\operatorname{MRR}\left(\mathrm{mm}^{3} / \mathrm{min}\right)$ & \\
\hline \multicolumn{5}{|c|}{$\begin{array}{l}\text { Fixed parameters: Wire material: brass; Wire diameter: } 0.25 \mathrm{~mm} \text {; Wire tension: } 1200 \text { grams, Dielectric: } \\
\text { de-ionized water; Dielectric conductivity: } 20 \mu \mathrm{S} / \mathrm{cm} \text {; Dielectric pressure: } 7 \mathrm{~kg} / \mathrm{cm}^{2} \\
\text { Miniature gear specifications: Material: brass; Profile: involute; Type: external spur gear; Pressure } \\
\text { angle: } 20^{0} \text {; Module: } 0.7 \mathrm{~mm} \text {; Outside diameter: } 9.8 \mathrm{~mm} \text {; Number of teeth: } 12 \text {; Face width: } 5 \mathrm{~mm} \text {. } \\
\text { *Cutting speed was fixed during main and confirmation experiments. }\end{array}$} \\
\hline
\end{tabular}

Tab. 3. Details of different stages of the experimentation

The main experiments were aimed to optimize the quality of the miniature gears by minimizing the geometric inaccuracy (i.e. profile and pitch errors), maximizing the surface finish (by minimizing average and maximum roughness), and the material removal rate (MRR). The main Experiments were designed using Box-Behnken approach of response surface methodology (Montgomery, 2009) by varying voltage, pulse-on time, pulse-off time and wire feed rate at three levels each. The 'Design Expert 8.0' software was used for regression and graphical analysis of the data obtained. Total 29 experiments were conducted with two replicates for the each experiment. Therefore, total 58 gears were manufactured. The values and ranges of fixed parameters were chosen based on the preliminary experiments (Gupta and Jain 2013) and the machine constraints. Analysis of variance (ANOVA) study based regression analysis was done to analyze the experimental data, to develop the relation between responses and WEDM parameters and to find the relative importance of the 
machining parameters with respect to the measures of performance (i.e. responses). The optimum values of the selected variables were obtained by solving the regression equations and by analyzing, the response surface contour plots. Finally, the confirmation experiments were conducted to validate the optimized results predicted by desirability analysis.

\section{Manufacturing of Miniature Gears by WEDM}

The miniature gears for the present research work were manufactured on Ecocut WEDM machine from Electronica India. This machine is based on closed-loop control system and having tolerance of $\pm 15 \mu \mathrm{m}$. The machine tool comprises of a main work table (called as X-Y table) and a wire drive mechanism. The gear blank (5 mm thick copper plate) is mounted and clamped on the main work table. It moves along $\mathrm{X}$ and $\mathrm{Y}$ axes, in steps of 1 micron, by means of stepper motor. A traveling wire which is continuously fed from wire feed spool is caused to travel through the plate and goes finally to the waste-wire box. Along its traveling path, the wire is supported under tension, between a pair of wire guides which are disposed on both (lower and upper) sides of the gear blank. As the material removal or machining proceeds, the work table carrying the gear blank is displaced transversely along a predetermined path (based on the geometry of the miniature gear) which is stored in terms of linear and circular elements in the controller via numeric control program and tries to maintain constant machining gap. While the machining is continued, the machining zone is continuously flushed with de-ionized water as dielectric passing through the nozzles on both sides of the gear blank. An ion exchange resin is used in dielectric distribution system, in order to prevent the increase in conductivity and to maintain the conductivity of the water constant.

Part programs for manufacturing of miniature gears on WEDM were prepared by Elcam software which has a separate segment for gear profile creation. The gear profile geometry is defined in terms of various geometrical definitions (lines and arcs) as the wire-tool path elements on graphical screen. The wire compensation (offset) for wire diameter and machining overcuts was specified. After the profile is fed to the computer, all the numerical information about the path is calculated automatically in terms of geometric and miscellaneous codes ( $\mathrm{G}$ and $\mathrm{M}$ codes). The entered gear profile was verified on the graphic display screen with simulation facility. The numeric control program for gear profile was then transferred to the machine tool by RS 232 cable. The miniature gears were manufactured from a $5 \mathrm{~mm}$ thick rectangular brass plate using brass wire of $0.25 \mathrm{~mm}$ diameter and de-ionized water as dielectric. The process sequence for manufacturing of miniature gears is depicted by Fig 3.

Profile error $\left(F_{a}\right)$ and pitch error $\left(F_{p}\right)$ were measured on the SmartGEAR CNC gear metrology machine. The measurements were taken on the left and right flanks of four gear teeth for profile error and on both the flanks of all the twelve teeth for the pitch error. Profile error $\left(F_{a}\right)$ was calculated by taking average of the mean values of the deviations in left flank (LF) and right flank (RF) of four gear teeth. While pitch error $\left(F_{p}\right)$ was calculated by taking average of the maximum differences in angular 
positions of RF and LF for all twelve teeth. The surface roughness parameters i.e. average roughness $\left(R_{a}\right)$ and maximum roughness $\left(R_{t}\right)$ were evaluated using Surfcom roughness profiler from Accretech, Japan on an evaluation length of $0.75 \mathrm{~mm}$ on gear tooth flank surface along root to tip using $0.25 \mathrm{~mm}$ as cut-off length. For evaluation of the $M R R$, a weighing scale having resolution of 10 milligrams is used for taking the weights of the gear blank (plate of brass) before and after machining, and the machining time is recorded by a stop watch having least count of 0.01 second. The following equation was used to determine the MRR value:

$$
M R R=\frac{M_{1}-M_{2}}{\rho \times t}\left(\mathrm{~mm}^{3} / \mathrm{min}\right)
$$

Where, $M_{1}$ and $M_{2}$ are the weights of the gear blank in grams before and after gear manufacturing by WEDM respectively; $\rho$ is the density of the gear material in $\mathrm{g} / \mathrm{mm}^{3}$ (for brass it is $0.0084 \mathrm{~g} / \mathrm{mm}^{3}$ ); and $t$ is the machining time in minutes.

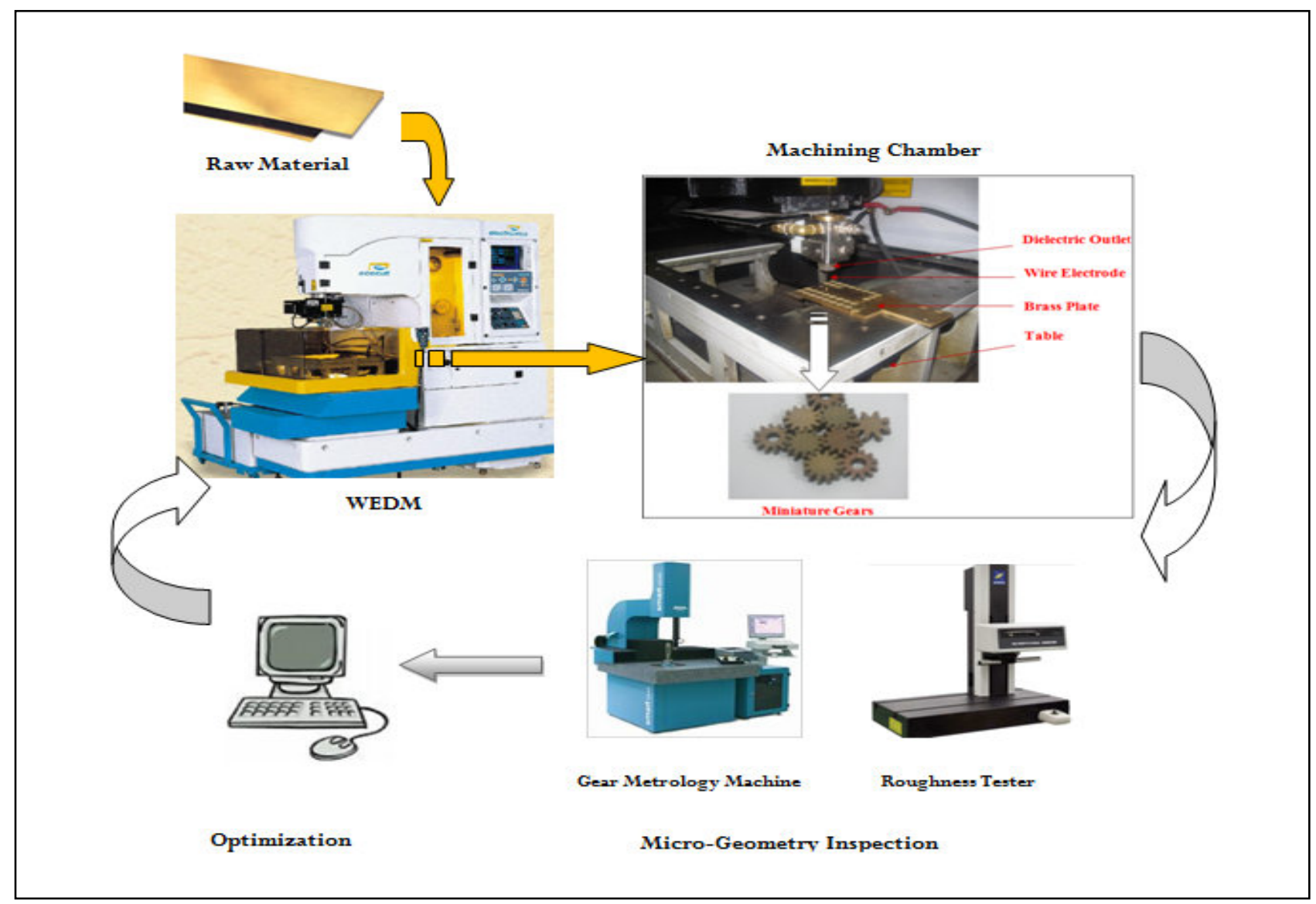

Fig. 3. Process sequence for manufacturing of miniature gears by WEDM

\section{Results and Discussion}

\subsection{Results of Pilot Experiments}

Keeping in view the objectives of minimizing the total profile error, accumulated pitch error and surface roughness simultaneously, $5-15 \mathrm{~V}$ for voltage, $0.6-1.0 \mu \mathrm{s}$ for pulse-on time, $90-170 \mu$ s for pulse-off time, $9-15 \mathrm{~m} / \mathrm{min}$ for wire feed rate with 100 
Gupta, K. \& Jain, N.K.: Manufacturing of High Quality Miniature Gears by Wire E...

$\%$ cutting speed have been bracketed for further detailed investigations (Gupta and Jain, 2013a-b). The best quality miniature gear manufactured by WEDM using the combination of $15 \mathrm{~V}$ voltage, $1 \mu \mathrm{s}$ pulse-on time, $170 \mu \mathrm{s}$ pulse-off time, $9 \mathrm{~m} / \mathrm{min}$ wire feed rate and $100 \%$ cutting speed, had DIN quality number of 6 for pitch (with pitch error of $11.2 \mu \mathrm{m}$ ), and DIN quality number of 8 for profile (with profile error of 13.2 $\mu \mathrm{m})$. The values of average and maximum roughness for this gear were $1.1 \mu \mathrm{m}$ and $6.4 \mu \mathrm{m}$ respectively. The set of parameters for best quality gear generated crack-free, regular shaped shallow cratered teeth surfaces. No dominant pattern of microhardness variation, in case of the best quality gear, with respect to the depth was noticed. This indicates either the absence or very small thickness of recast layer and heat affected zone. This gear also had very low macro-geometry deviations i.e. deviation in span $(4 \mu \mathrm{m})$, deviation in chordal tooth thickness $(5 \mu \mathrm{m})$, deviation in the dimension over two balls $(10 \mu \mathrm{m})$. Fig. 4 depicts the SEM images of the this gear showing (a-b) the uniform burr-free tooth profile (c) defect-free surface of the gear tooth (d) arrangements of craters on the WEDMed surface of the tooth of the best gear.

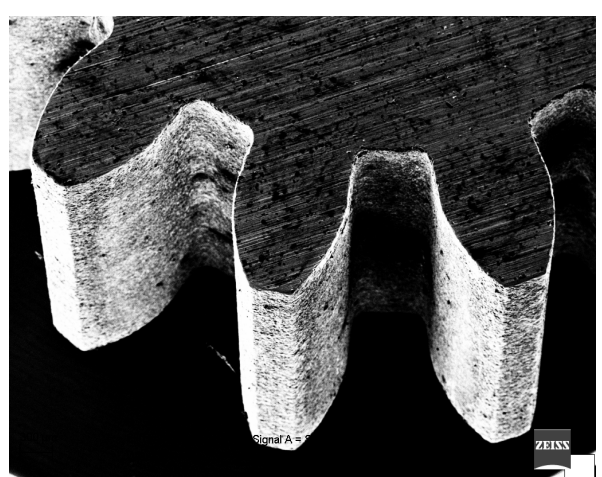

(a) at $50 \mathrm{X}$

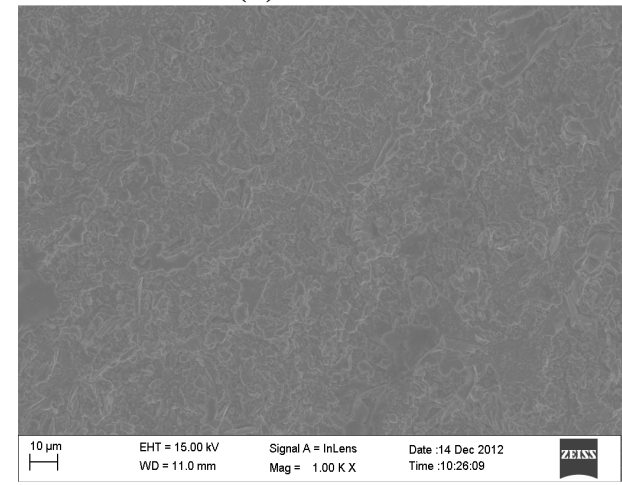

(c) at $1000 \mathrm{X}$

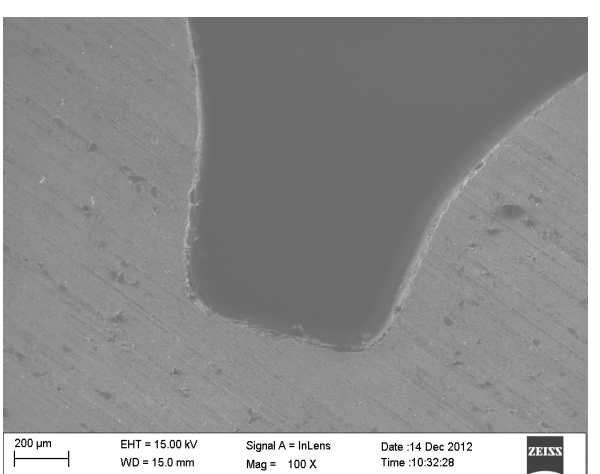

(b) at $100 \mathrm{X}$

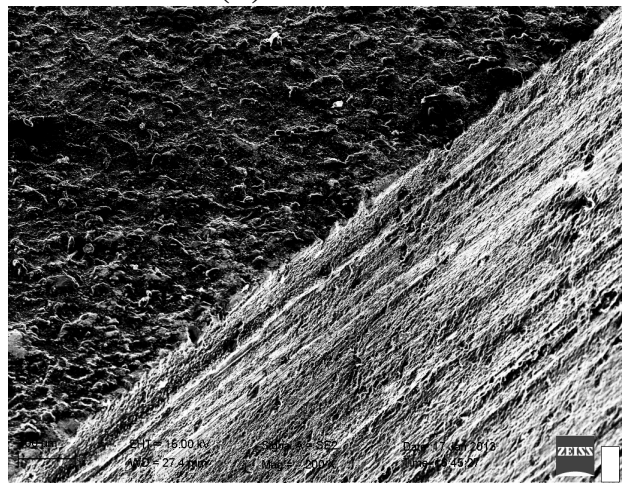

(d) at $300 \mathrm{X}$

Fig. 4. SEM images (a) and (b) proturbance-free gear teeth profile; (c) smooth crackfree texture of the best tooth surface; (d) uniform distribution of regular craters on tooth surface

Results of the experiments proved the capability of WEDM for manufacturing high quality miniature gears. Main experiments were conducted for analysing the 
behaviour of micro-geometry with WEDM parameters and to improve the quality of the miniature gears.

\subsection{Results of Main Experimentation}

Twenty nine main experiments were conducted according to Box-Behnken approach of RSM. Table 4 presents the parametric combinations and corresponding responses for the different experimental runs. ANOVA has been used to study the significant WEDM parameters.

\begin{tabular}{|c|c|c|c|c|c|c|c|c|c|}
\hline \multirow[b]{2}{*}{$\begin{array}{c}\text { Expt. } \\
\text { No. }\end{array}$} & \multicolumn{4}{|c|}{ Input Parameters } & \multicolumn{5}{|c|}{ Responses } \\
\hline & $\begin{array}{c}\mathbf{V} \\
\text { (Volts) } \\
\end{array}$ & $\begin{array}{l}\mathbf{T}_{\text {on }} \\
(\mu \mathrm{s})\end{array}$ & $\begin{array}{l}\mathbf{T}_{\text {off }} \\
(\mu \mathrm{s})\end{array}$ & \begin{tabular}{c|c|}
$\mathbf{W}$ \\
$(\mathbf{m} / \mathbf{m i n})$
\end{tabular} & $\begin{array}{c}{ }^{\prime} \mathbf{F}_{\mathbf{a}}{ }^{\prime} \\
(\mu \mathrm{m}) \\
\end{array}$ & $\begin{array}{c}' \mathbf{F}_{\mathbf{p}}{ }^{\prime} \\
(\mu \mathbf{m}) \\
\end{array}$ & $\begin{array}{c}' \mathbf{R}_{\mathbf{a}}{ }^{\prime} \\
(\mu \mathbf{m})\end{array}$ & $\begin{array}{c}' \mathbf{R}_{\mathbf{t}} \text { ' } \\
(\mu \mathrm{m})\end{array}$ & $\begin{array}{c}\text { MRR } \\
\left(\mathrm{mm}^{3} / \mathrm{min}\right)\end{array}$ \\
\hline $\mathbf{1}$ & 15 & 0.8 & 130 & 15 & 14.20 & 30.20 & 1.70 & 7.40 & 38 \\
\hline 2 & 10 & 0.8 & 90 & 9 & 14.50 & 41.00 & 2.00 & 9.20 & 42.5 \\
\hline 3 & 5 & 1.0 & 130 & 12 & 14.00 & 29.40 & 1.80 & 8.72 & 25.68 \\
\hline 4 & 10 & 0.8 & 130 & 12 & 13.10 & 12.40 & 1.40 & 7.23 & 28 \\
\hline 5 & 15 & 0.6 & 130 & 12 & 14.00 & 24.20 & 1.44 & 7.14 & 25.46 \\
\hline 6 & 5 & 0.8 & 130 & 9 & 14.40 & 32.10 & 1.70 & 8.00 & 31.4 \\
\hline 7 & 5 & 0.8 & 170 & 12 & 13.00 & 19.20 & 1.35 & 6.87 & 17.8 \\
\hline 8 & 10 & 1.0 & 130 & 9 & 14.60 & 44.50 & 1.82 & 8.85 & 35.58 \\
\hline 9 & 15 & 0.8 & 130 & 9 & 14.80 & 38.60 & 1.76 & 8.55 & 38 \\
\hline 10 & 10 & 0.8 & 170 & 15 & 13.10 & 18.10 & 1.28 & 7.01 & 27.6 \\
\hline 11 & 15 & 0.8 & 170 & 12 & 14.40 & 35.00 & 1.71 & 7.30 & 28.2 \\
\hline 12 & 15 & 1.0 & 130 & 12 & 15.20 & 40.80 & 1.92 & 8.90 & 42.42 \\
\hline 13 & 10 & 0.8 & 130 & 12 & 12.80 & 16.25 & 1.65 & 7.00 & 30.5 \\
\hline 14 & 10 & 0.8 & 130 & 12 & 12.50 & 11.80 & 1.70 & 6.78 & 34 \\
\hline 15 & 10 & 0.8 & 130 & 12 & 13.10 & 15.00 & 1.60 & 6.90 & 27.8 \\
\hline 16 & 15 & 0.8 & 90 & 12 & 14.80 & 35.70 & 1.87 & 8.70 & 36.4 \\
\hline 17 & 10 & 0.8 & 170 & 9 & 13.80 & 32.40 & 1.68 & 7.80 & 25.54 \\
\hline 18 & 10 & 1.0 & 90 & 12 & 13.90 & 38.00 & 1.97 & 9.80 & 40.73 \\
\hline 19 & 5 & 0.8 & 90 & 12 & 14.30 & 34.00 & 1.61 & 8.20 & 28 \\
\hline 20 & 10 & 0.8 & 130 & 12 & 13.00 & 18.20 & 1.76 & 7.11 & 32 \\
\hline 21 & 10 & 0.6 & 90 & 12 & 14.20 & 28.35 & 1.63 & 7.30 & 28.16 \\
\hline 22 & 10 & 0.6 & 170 & 12 & 11.70 & 8.30 & 1.40 & 7.00 & 24 \\
\hline 23 & 10 & 0.8 & 90 & 15 & 13.50 & 25.10 & 1.55 & 8.23 & 32.45 \\
\hline 24 & 10 & 1.0 & 130 & 15 & 14.00 & 27.00 & 1.74 & 8.70 & 37.17 \\
\hline 25 & 5 & 0.6 & 130 & 12 & 13.30 & 20.65 & 1.14 & 6.72 & 16.08 \\
\hline 26 & 10 & 0.6 & 130 & 9 & 13.50 & 25.00 & 1.49 & 7.45 & 30.64 \\
\hline 27 & 10 & 1.0 & 170 & 12 & 14.60 & 32.80 & 1.65 & 7.90 & 28.8 \\
\hline 28 & 5 & 0.8 & 130 & 15 & 13.00 & 22.40 & 1.25 & 6.75 & 22 \\
\hline 29 & 10 & 0.6 & 130 & 15 & 12.00 & 16.00 & 1.18 & 6.90 & 20.26 \\
\hline
\end{tabular}

Tab. 4. Experimental runs and corresponding responses for main experimentation 
Gupta, K. \& Jain, N.K.: Manufacturing of High Quality Miniature Gears by Wire E...

ANOVA study found that all four WEDM parameters significantly affect the profile error, pitch error, average roughness, maximum roughness and MRR. Figures 5 and 6 illustrates the variation of the response surfaces for $F_{a}$ (Fig. 5a and 5b), $F_{p}$ (Fig. 5c and 5d) and $R_{t}$ (Fig. 6a and 6b) with the WEDM parameters. It can be observed that the minimum values of $F_{a}$ and $F_{p}$ are obtained in the range of 8-9 volts (Fig. 5a and 5c). This is due to fact that at very low voltage, high amount of wire lag is caused by high electrostatic force while, higher values of voltage and pulse-on-time lead to generation of larger forces caused by violent spark and pressure of the gas bubbles. It can be seen from Fig. $5 \mathrm{~b}$ and $5 \mathrm{~d}$ that there exists an optimum range for pulse-off time (140-160 $\mu \mathrm{s})$ and wire feed rate $(12.5-14 \mathrm{~m} / \mathrm{min})$. It can be explained by the fact that lower pulse-off time and wire feed rate causes wire vibrations due to short circuiting while, their higher values cause excessive hydraulic forces resulting in wire lag and again increasing errors in profile and pitch.

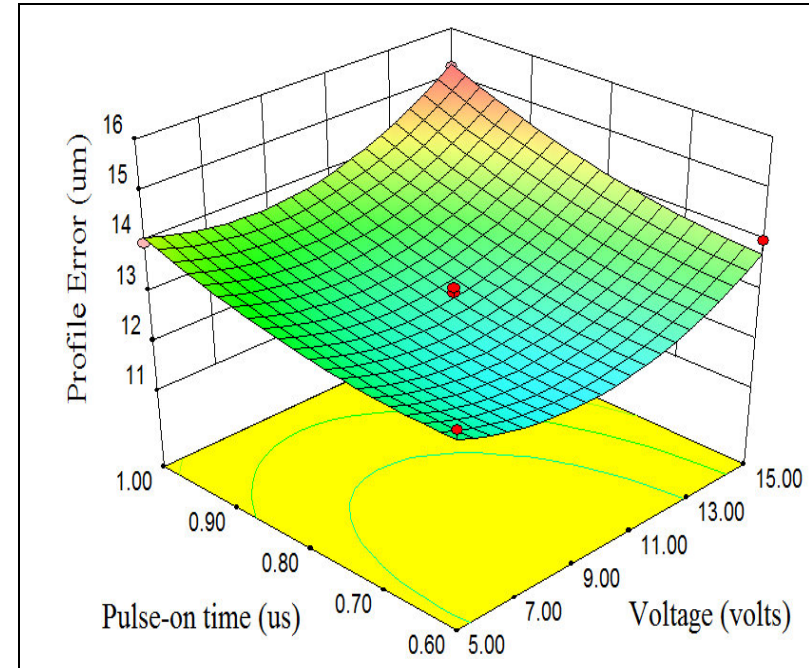

(a)

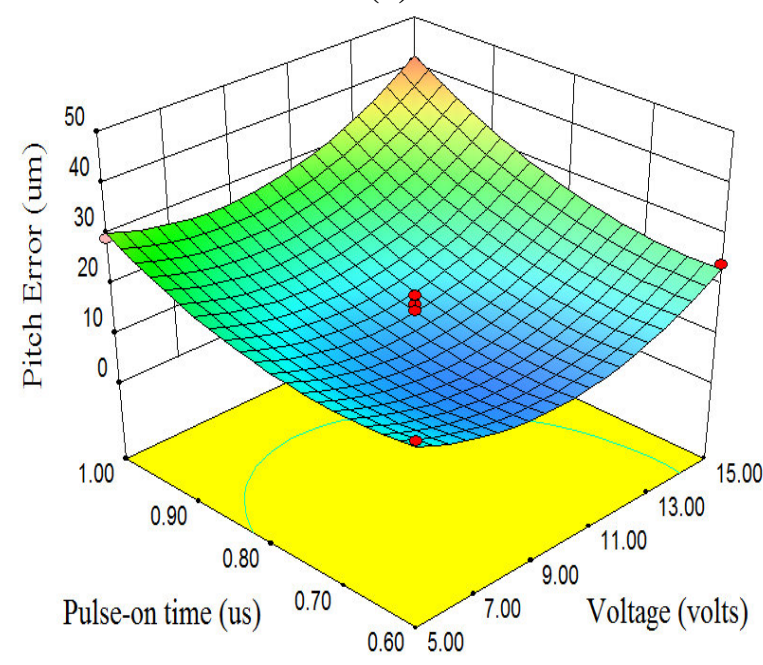

(c)

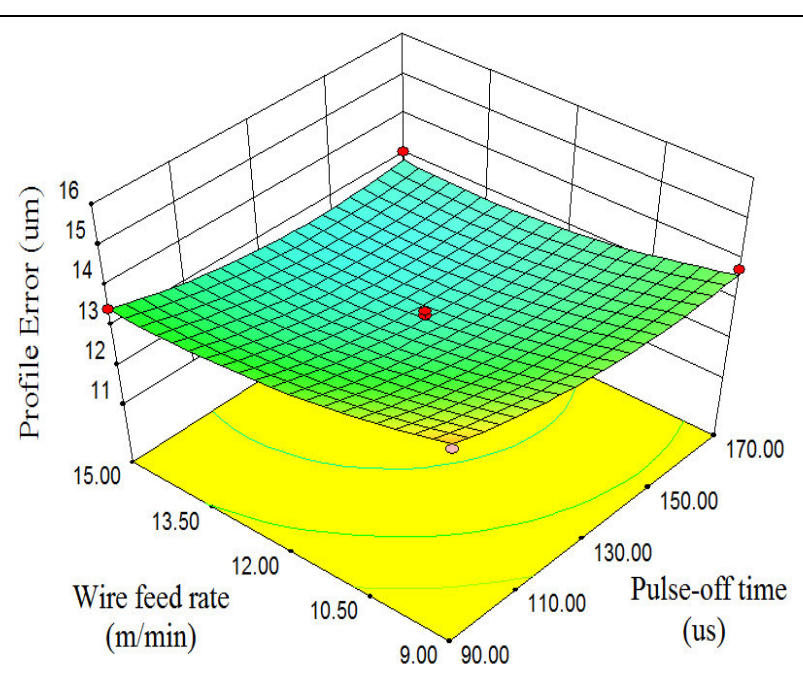

(b)

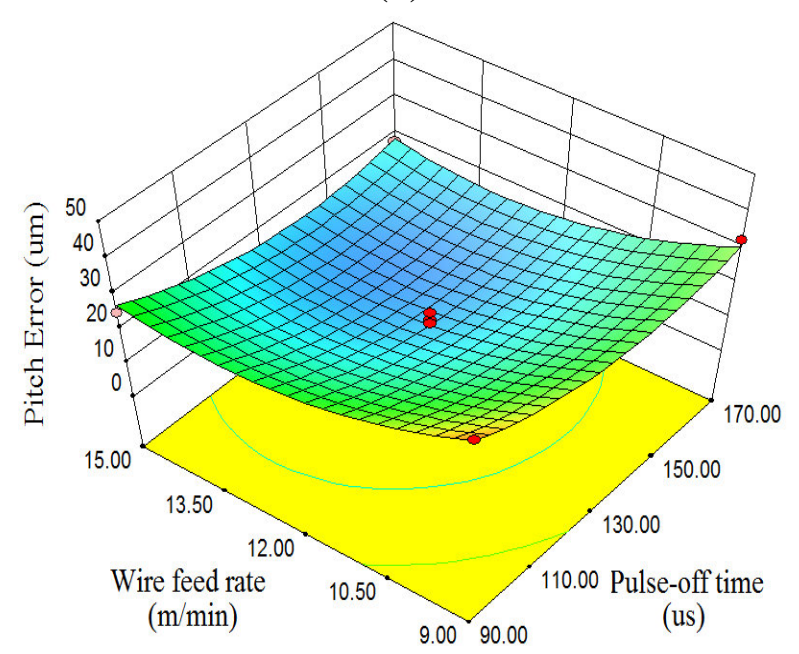

(d)

Fig. 5. Variation of $F_{a}$ and $F_{p}$ with WEDM parameters

It is evident from the Figures $6 a$ and $6 b$ that the optimum ranges of voltage (6-8 $\mathrm{V})$, pulse-on time (0.6-0.7 $\mu \mathrm{s})$, pulse-off time (150-160) and wire feed rate (12.5-14.5 $\mathrm{m} / \mathrm{min}$ ) exist for minimum $R_{t}$. While, variation of $R_{a}$ is linear with WEDM 
parameters i.e. lowest voltage and pulse-on time (Fig. 7a) and highest pulse-off time and wire feed rate (Fig. 7b) should be used to minimize $R_{a}$. It can be explained by as follows. Use of higher voltage, longer pulse-on time and shorter pulse-off time increases the discharge energy at the plasma channel, availability of time for transfer of this energy to the gear tooth surface and decreases the flushing time. While, lower wire feed rate increases frequency of wire breakage. All these factors lead to formation of deeper and irregular craters on the gear tooth surface increasing the surface roughness value.

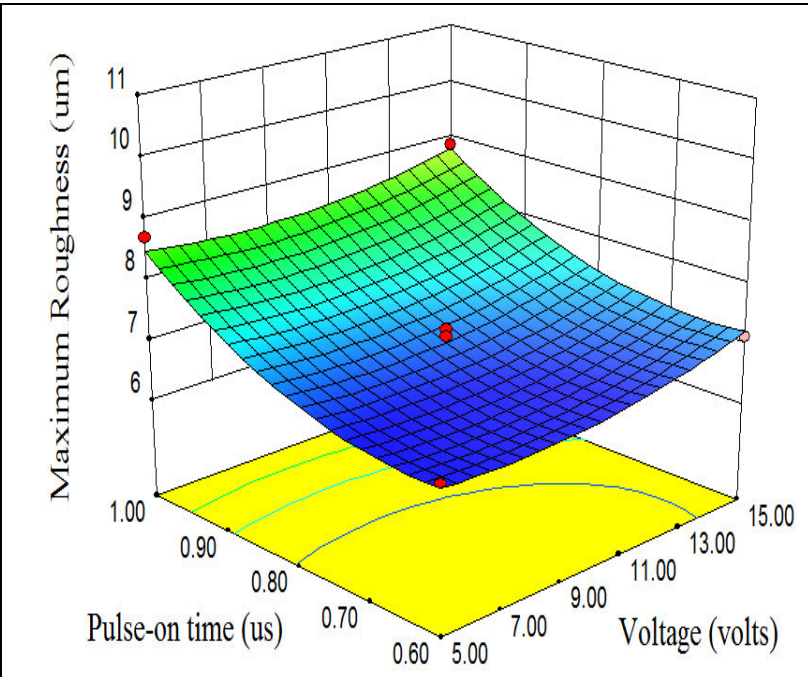

(a)

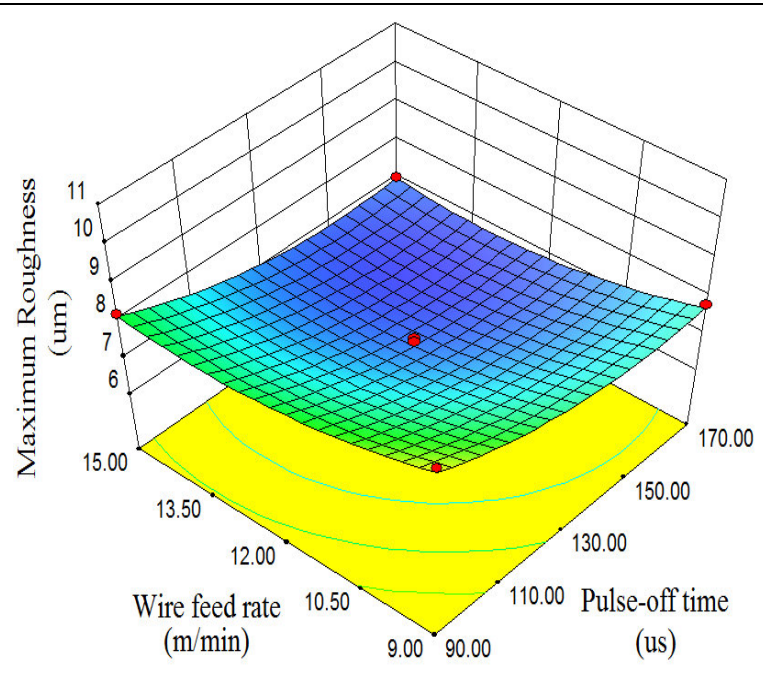

(b)

Fig. 6. Variation of $R_{t}$ with WEDM parameters

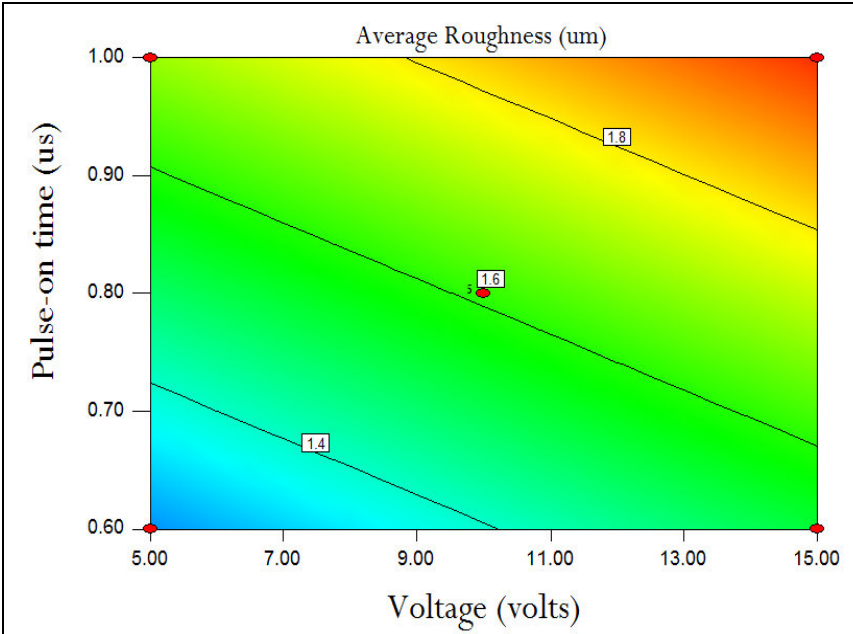

(a)

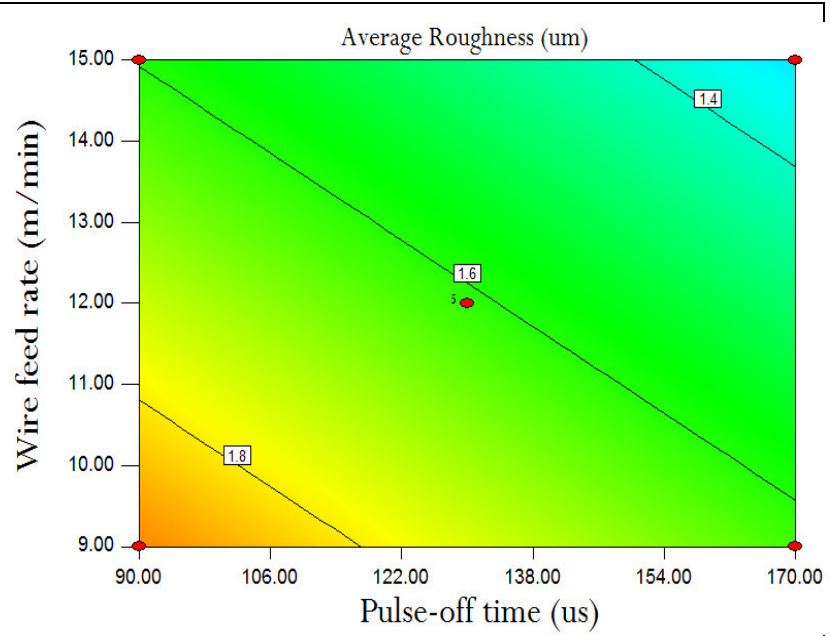

(b)

Fig. 7. Variation of $R_{a}$ with WEDM parameters

Fig. 8 shows the effects of WEDM parameters on MRR. It can be seen that higher MRR can be achieved using higher voltage, longer pulse-on time, shorter pulse-off time and lower wire feed rate. Increase in voltage and pulse-on time leads to increase in MRR because strong electric field at higher voltage facilitates the ionization of dielectric and thereby increase in discharge and increase in the period of 
Gupta, K. \& Jain, N.K.: Manufacturing of High Quality Miniature Gears by Wire E...

transferring of discharge energy to the electrodes which results in rapid melting and evaporation of large amount of material.

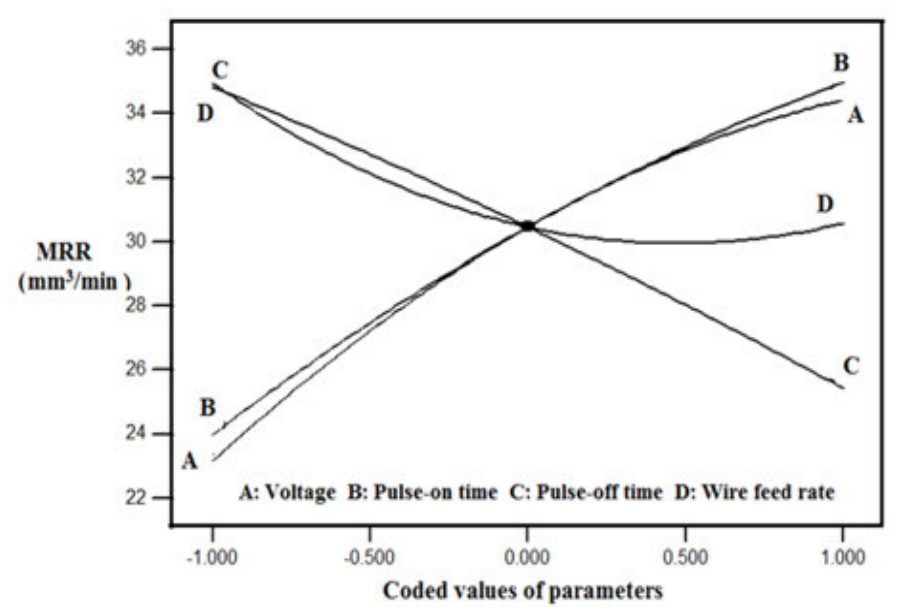

Fig. 8. Effect of WEDM parameters on $M R R$

\subsection{Optimization}

In order to get precise quality and productivity, the understanding and control of any process are the prerequisites and can only be achieved by accurate modelling and optimization of the process and its parameters. The single-objective optimization of WEDM parameters was done for minimum values of $F_{a}, F_{p}, R_{a}, R_{t}$ and for maximum value of $M R R$.

\subsubsection{Desirability analysis}

Desirability analysis uses desirability function which is the geometric mean of the individual desirabilities of all the responses and tries to find the optimum values of the process parameters to meet the goal of the desirability function. Each response $Y_{i}$ is converted into an individual desirability function $d_{i}$ whose value can range from 0 (when the response is outside the acceptable region) to 1 (when the response is at its goal or target value). The more closely the response approaches the goal or target value, the closer is the desirability to 1. Equation (2) presents the generalized equation of the desirability function for the $i^{\text {th }}$ data:

$$
D_{i}=\left(\prod_{j=1}^{n} d_{i j}\right)^{\frac{1}{n}}
$$

Where, $n$ is number of responses; $d_{i j}$ is the desirability of the $j^{t h}$ response for the data with $0 \leq d_{i j} \leq 1$.

In the present case there are five responses $F_{a}, F_{p}, R_{a}, R_{t}$ and $M R R$. For each response the optimized values of WEDM parameters were predicted by desirability approach. The individual desirabilities for $F_{a}, F_{p}, R_{a}, R_{t}$ and $M R R$ for the $i^{\text {th }}$ data were calculated by following equations (Montgomery, 2009): 


$$
\begin{aligned}
\left(d_{F_{a}}\right)_{i} & =\left[\frac{F_{a_{\max }}-F_{a_{i}}}{F_{a_{\max }}-F_{a_{\min }}}\right] \\
\left(d_{R_{a}}\right)_{i} & =\left[\frac{R_{a_{\max }}-R_{a_{i}}}{R_{a_{\max }}-R_{a_{\min }}}\right] \\
\left(d_{M R R}\right)_{i} & =\left[\frac{M R_{i}-M R R_{\min }}{M R_{\max }-M R R_{\min }}\right]
\end{aligned}
$$

$$
\begin{aligned}
& \left(d_{F_{P}}\right)_{i}=\left[\frac{F_{P_{\max }}-F_{P_{i}}}{F_{P_{\max }}-F_{P_{\min }}}\right] \\
& \left(d_{R_{t}}\right)_{i}=\left[\frac{R_{t_{\max }}-R_{t_{i}}}{R_{t_{\max }}-R_{t_{\min }}}\right]
\end{aligned}
$$

Where, $i$ is the value of $i$ th response obtained min and max are the minimum and maximum values of the responses.

\subsection{Confirmation Experiments}

The optimum values of the WEDM parameters obtained through desirability analysis for each response were standardized based on machine constraints and are

\begin{tabular}{|c|c|c|c|c|c|c|c|c|c|c|}
\hline \multirow[t]{3}{*}{ Responses } & \multicolumn{8}{|c|}{ WEDM parameters } & \multicolumn{2}{|c|}{ Values of response from } \\
\hline & \multicolumn{4}{|c|}{ Optimized } & \multicolumn{4}{|c|}{ Standardized } & \multirow{2}{*}{$\begin{array}{c}\text { Desirability } \\
\text { analysis }\end{array}$} & \multirow{2}{*}{$\begin{array}{l}\text { Confirmation } \\
\text { Experiments }\end{array}$} \\
\hline & $\boldsymbol{V}$ & $T_{\text {on }}$ & $T_{\text {off }}$ & $\boldsymbol{W}$ & $\boldsymbol{V}$ & $T_{o n}$ & $T_{\text {off }}$ & $\boldsymbol{W}$ & & \\
\hline $\boldsymbol{R}_{a}$ & 6.31 & 0.61 & 164.01 & 14.47 & 6 & 0.6 & 165 & 15 & 1.07 & 1.10 \\
\hline $\boldsymbol{R}_{t}$ & 7.61 & 0.61 & 149.86 & 14.13 & 8 & 0.6 & 150 & 14 & 6.48 & 6.40 \\
\hline $\bar{F} F_{a}$ & 8.14 & 0.60 & 165.36 & 12.99 & 8 & 0.60 & 160 & 13 & 11.58 & 11.10 \\
\hline $\begin{array}{c}\boldsymbol{F}_{\boldsymbol{p}} \\
* D: 0.983 \\
\end{array}$ & 8.71 & 0.64 & 154.15 & 12.87 & 9 & 0.65 & 150 & 13 & 8.91 & 8.4 \\
\hline$M R R$ & 14.8 & 0.83 & 97.14 & 9.18 & 15 & 0.85 & 100 & 9 & 42.81 & 42.97 \\
\hline
\end{tabular}
given in Table 5. On these standardized optimum values of WEDM parameters, the confirmation experiments were conducted to validate the predicted results. Very close agreement found between the experimental results and those obtained by the desirablity analysis.

Tab. 5. Comparison of optimum values with the results of confirmation experiment for $F_{a}, F_{p}, R_{a}, R_{t}$ and $M R R$

Fig. 9 depicts SEM images of the miniature gears manufactured at optimal parameters. It is clear that miniature gears have burr-free uniform tooth profile.

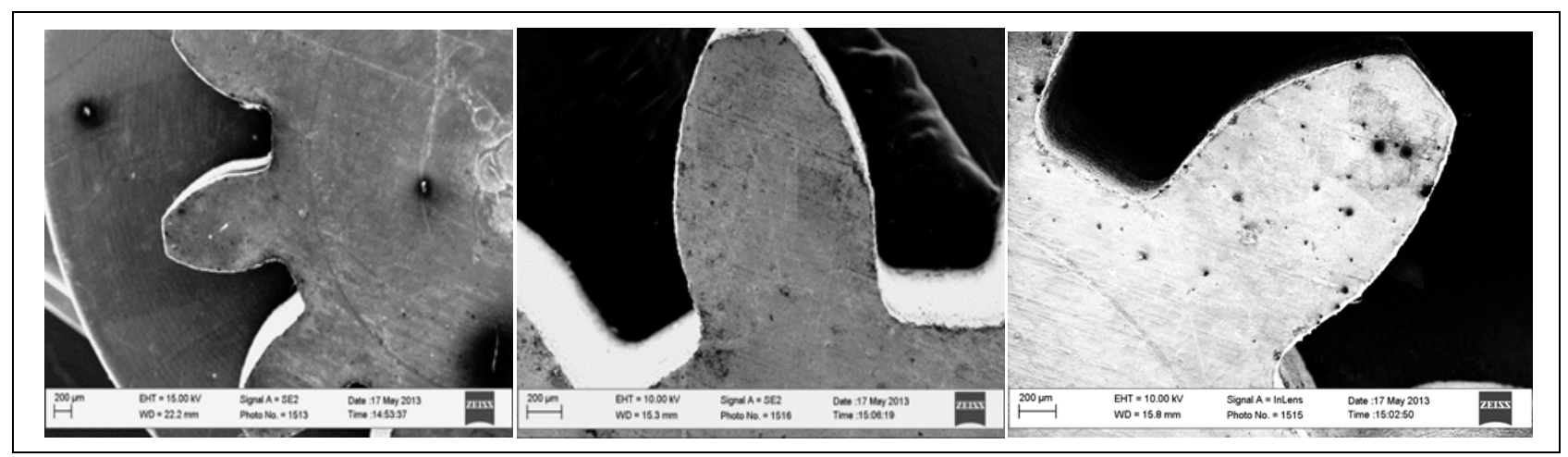

Fig. 9. SEM images of Miniature gear manufactured at optimal parameters 
Gupta, K. \& Jain, N.K.: Manufacturing of High Quality Miniature Gears by Wire E...

\section{Conclusions and Future Scope}

As the demand of the miniaturized devices continues to grow, the requirement of high quality miniature gears is ever increasing. The results of the present work would be very useful to engineers and manufacturers for manufacturing of high quality miniature gears by wire electric discharge machining. This chapter reported about the investigations on the effects of WEDM parameters on the profile error, pitch error, average roughness, maximum roughness and material removal rate of miniature gears. This chapter also describes the single objective optimization of WEDM parameters for minimization of profile error, pitch error, average roughness and maximum roughness, and maximization of MRR. Following conclusions can be drawn from the present work:

1. Voltage, pulse-on time, pulse-off time and wire feed rate were found to be highly significant parameters.

2. Main reasons of errors in profile and pitch, and surface roughness are irregular shaped craters created due to violent sparks having high discharge energy, short circuiting and adherence of wire on gear tooth surface, and wire-lag due to various forces generated during machining.

3. It was also found that WEDMed miniature gears had burr-free uniform profile, defect free surfaces and very thin recast layer.

4. Optimization was done to improve the quality and productivity of WEDMed miniature gears. Confirmation experiments revealed very close agreement between predicted and experimental results of optimization.

5. The optimized values of profile $(11.1 \mu \mathrm{m})$ and pitch $(8.4 \mu \mathrm{m})$ categorize the gear in high quality i.e. DIN quality number 7 and 5 respectively, which are superior than the other existing conventional processes of miniature gear manufacturing.

6. The results of the present work prove the superiority and capability of WEDM to manufacture high quality miniature gears for the miniaturized devices.

Similar work can also be done for miniature gears of different materials such as stainless steel, bronze, aluminium and other metallic materials. Wires of different materials and types can be used to manufacture miniature gears and effect of the same can be analyzed on the quality of miniature gears. High end WEDM machine tool having minimum constraints can be used to analyze the effect of other WEDM parameters such as current, wire tension, flushing pressure etc. on the quality of miniature gears.

\section{Acknowledgements}

Authors wish to acknowledge the cooperation from Carl Zeiss technology centre, Pune (India) for the surface roughness measurements of the miniature gears by surface profiler Surfcom 


\section{References}

Ali, M.Y.; Karim, A.N.M.; Adesta, E.Y.T.; Ismail, A.F.; Abdullah, A.A. \& Idris, M.N. (2010) Comparative study of conventional and micro WEDM based on machining of meso/micro sized spur gear, International Journal of Precision Engineering and Manufacturing, Vol., 11(5), 779-784, 20054602

Ali, M.Y. \& Mohammad, A.S. (2008) Experimental study of conventional WEDM for micro-fabrication, Materials and Manufacturing Processes, Vol., 23(7), 641-645, 15322475

Arunachalam, C.; Aulia, M.; Bozkurt, B. \& Eubank, P. T. (2001) Wire vibration, bowing, and breakage in wire electrical discharge machining, Journal of Applied Physics, Vol., 89 (8), 4255-4262, 10897550

Benavides, G.L.; Bieg, L.F.; Saavedra, M.P. \& Bryce, E.A. (2002) High aspect ratio meso-scale parts enabled by wire micro-EDM. Microsystem Technologies, Vol., 8, 395-401, 14321858

Benedict, G.F. (1987) Nontraditional manufacturing processes, Marcel Dekker, 0844706447, New York

Bralla, J. (1998) Design for manufacturability handbook, Tata McGraw-Hill, 0070071391, New York

Davim, P.J. (2010) Surface integrity in machining, Springer, 1848828742, London

Davis, J.R. (2005) Gear Materials, Properties, and Manufacture, ASM International, 0871708151, Ohio

Di, S.; Haung, R. \& Chi, G. (2006) Study on micro-machining by micro-WEDM. Proceedings of the $1^{\text {st }}$ IEEE Conference on Nano/Micro Engineered and Molecular systems, pp. 615-619, , Zhuhai, China

Goch, G. (2003) Gear Metrology, Annals of CIRP, Vol., 52, 659-695

Gupta, K. \& Jain, N.K. (2013) Deviations in geometry of miniature gears fabricated by WEDM. ASME International Mechanical Engineering Congress and Exposition 2013, 15-21 Nov 2013, San Diego, USA

Gupta, K. \& Jain, N.K. (2013) On micro-geometry of miniature gears manufactured by WEDM, Materials and Manufacturing Processes, Vol., 28, 1-7, 15322475

Ho, K.H.; Newman, S.T.; Rahimifard, S. \& Allen, R.D. (2004) State of the art in wire electrical discharge machining, International Journal of Machine Tools and Manufacture, Vol., 44, 1247-1259, 08906955

Hsu, T.R. (2008) MEMS and microsystems design, manufacture and nano scale Engineering, John Wiley \& Sons, 0470083017, New Jersey

Jain, V.K. (2008) Advanced machining processes, Allied Publishers, 8177642944, New Delhi

Kanlayasiri, K. \& Jattakul, P. (2013) Simultaneous optimization of dimensional accuracy and surface roughness for finishing cut of wire-EDMed K460 tool steel. Precision Engineering, Vol., 37, 556-561, 01416359

Kuruvila, V. \& Ravindra, H.V. (2011) Parametric influence and optimization of Wire EDM of hot die steel, Machining Science and Technology, Vol.,15, 47-75, 15322483 
Gupta, K. \& Jain, N.K.: Manufacturing of High Quality Miniature Gears by Wire E...

Liao, Y.S.; Huang, J.T. \& Chen, Y.H. (2004) A study to achieve fine surface finish in wire-EDM, Journal of Material Processing Technology, Vol., 149, 165-171, 09240136

McGeough, J.A. (1988) Advanced Methods of Machining; Chapman and Hall Ltd, 0412319705, London

Mingqi, L.; Minghui, L. \& Guangyao, X. (2005) Study on the variations of Form and position of the wire electrode in WEDM-HS, International Journal of Advanced Manufacturing Technology, Vol., 25, 929-934, 14333015

Montgomery, D.G. (2009) Design and analysis of experiments, John Willey \& Sons, 8126528370, New Delhi

Puri, A.B. \& Bhattacharyya, B. (2003) Analysis and optimization of the geometrical inaccuracy due to wire lag phenomenon in WEDM, International Journal of Machine Tools and Manufacture, Vol., 43 151-159, 08906955

Qin, Y. (2010) Micro-manufacturing engineering and technology, Elsevier, Oxford Takeuchi, H.; Nakamura, K.; Shimizu, N. \& Shibaike, N. (2000) Optimization of mechanical interface for a practical micro-reducer, Proceedings of the $13^{\text {th }}$ IEEE International Conference on Micro Electro Mechanical Systems, January 23-27, 2000, Miyazaki, Japan

Townsend, D.P. (2011) Dudley's Gear Handbook, Tata McGraw-Hill Publishing Company, 9780071077361, New Delhi

Tzeng, C.; Yang, Y. \& Hsieh, M. (2011) Optimization of wire electrical discharge machining of pure tungsten using neural network and response surface methodology, Proc IMechE, Part-B Journal of Engineering Manufacture, Vol., 225, 841-852, 20412975

Yusup, N.; Zain, A.M. \& Hashim, S.Z.M. (2012) Evolutionary techniques in optimizing machining parameters: Review and recent applications (2007-2011), Expert Systems with Applications, Vol., 39, 9909-9927, 09574174 